DOI https://doi.org/10.18551/rjoas.2018-06.14

\title{
THE IMPLEMENTATION OF VILLAGE FINANCE MANAGEMENT AT PORONG SUB-DISTRICT IN SIDOARJO REGENCY TO ACHIEVE «GOOD GOVERNANCE»
}

\author{
Choiri \\ Department of Law Science and Development, Post-graduate School, \\ Airlangga University, Indonesia \\ E-mail: choiri69@yahoo.co.id
}

\begin{abstract}
Finance management system of Porong sub-district in Sidarjo regency is recently accordance with the procedure of good governance principle. The plan, implementation, administration, report, and responsibility of the management are already well organized. Unfortunately, there are several aspects that violate the regulation of constitution. The lack of transparency and accountability of village governance become major problem while maintaining the system, they just used the system to complete the procedure instead of following good governance principle. Thus good governance principle is still not yet achieved at Porong sub-District.
\end{abstract}

\section{KEY WORDS}

Finance management, good governance, regulation of constitution, village governance.

In order to imply a good village, which is accordance with government implementation principle and village regulation principle, stated in constitution regulation number 6 of 2014 about village, there are some aspects concerned for this vision. They are law certainty, order of government implementation, order of public interest, transparency, professionalism, accountability, diversity, and participation. While concerning with village development, togetherness, humanity, and helping each other are priorities to imply social justice. All of those aspects need a well-organized finance management, government publish Government Rule (The phrase will be referenced as GR in this study) number 43 of 2014 about the regulation execution of ordinance number 6 of 2014 about Village which has been amend into GR number 47 of 2015 and the regulation of ministry of home affairs number 113 of 2014 about village finance management, it stated that village finance management is series of act which cover planning, implementation, administration, report, and responsibility. Sidoarjo government respond this statement by publishing regent regulation number 27 of 2015 act 2 about Village Finance Management Guidance stated that village finance must be managed with principles of transparency, accountable, participative, in order, and estimate discipline. As all of the aspects are implemented, the good governance of village finance system will be achieved. Because, the meaning of good governance is not only on the service of the government but also on the support o its people. Thus, god governance must be orientation and obeyed by every apparatus of the village government.

In the other hand, the reality reveals different expectation; there are several villages that do not yet possess formal finance management system for instance an event does not have any report of its administration record, expenditure blurred record, and no transparency of village finance use. Porong sub-district within Sidoarjo Regency is one of sub-district with most finance error report. Porong sub-district consist of 13 villages which are Kedungsolo, Pesawahan, Lajuk, Kebonagung, Pamotan, Kedungboto, Candipari, Kebakalan, Plumbon, Glagaharum, Kesambi, Renokenongo and Wunut.

There are several villages which unable to complete their finance system. Thus, this study would aim to observe all finance management record of the villages towards good governances principle. From the background above, the research question of this study is "how is the system of finance management at Porong sub-District of Sidoarjo Regency towards Good Governance principle?". 


\section{METHODS OF RESEARCH}

Socio legal is the suitable type for this study. It sees law as social phenomenon, thus, the law that will be studied on this paper will be used as basis point of view to observe subject of the study. Socio-legal is also known as society legal phenomenon or social fact which occurred among societies which social fact is a certain habit as role model for its people (Nasution, 2008:124).

The composition of source of data of this study is as follow:

- Literature study (secondary data) which known as legal materials in normative study;

- Field observation (primary data) which comes from respondents;

- Legal materials (tertiary data) which in form of scientific paper of the academies. Data collection:

- Literature data. This secondary data is in the form legal materials obtained by using stock taking (inventory) method. By using card system, the data will be specified into Ikhtisar card, Cite card, and Analysis card.

- Field observation data. The instrument to collect field observation data is by using pair of managed questionnaire. It consists of questions written and distributed to the respondents to obtain the responds or information of the question.

As the information is already gathered, the next step is to process the data. In order to process the data, the first step is editing the data and coding it. Then, the data is analysed within its content (content analysis). Thus, there will be stimulation for special analysis towards the content of the data, the context of the data is also important for the result accuracy as this study is one of case study paper.

\section{DISCUSSION OF RESULTS} follow:

Finance management system of Porong sub-district consists of several procedures, as

Planning. Village Development Planning Program covers Village RPJM and RKP which constructed in schedule and written based on Village law. Short Term Village Development Planning (RPJM) is conducted for 6 ofs period while Village Apparatus Work Planning period is only for 1 of. While conducting RPJM, Village Apparatus is mandatory to hold Village Development Conference participatively. As self governing community, village development planning is very important to keep up the track record of the village, it will be easier for the apparatus to maintain and improve the village quality. The planning program will consolidate the right and duty of the village itself, it will help the village to optimise their resources. From the result of study, the 13 villages of Porong sub-districts as objects of the study (Kedungsolo, Pesawahan, Lajuk, Kebonagung, Pamotan, Kedungboto, Candipari, Kebakalan, Plumbon, Glagaharum, Kesambi, Renokenongo and Wunut.), there are two villages which could not complete their finance management activity. They are Glagaharum and Renokenongo village, which, in some cases, they do not participate in BPD for finance management report. In one hand, not all villages have conducted their RPJM, RKP, and APB report. From 13 villages, 7 villages has completed their RPJM report while other 6 villages did not complete the report. Meanwhile, all village did not conduct their RKP report. This infraction does not match with Law number 6 of 2014 article 79 act 2, it stated that Village Work Planning is another definition of short term work planning for at least one of period.

RKP village report covers information of program priority, activity, basic need of village development from APB fund, Village Foundation Charity, and/or fund finance of Regent/City. There are two that did not submit their APBDes finance report, they are Renokenongo, which is unable to report because of mass nature disaster known as 'Lumpur Porong Lapindo', and Glagaharum village, which could not report their finance management with no clear reason. Glagaharum villge failed to report their finance management of APBD in 2017 and 2016 for about Rp. 232.000.000,-. This case is absolutely against the order of ministry of home affair number 113 of 2014 about finance management article 20, it states that APB plan which is 
offered by head of village to BPD will be reviewed until month of October and it will be evaluated by head of sub-District. In this case, BPD has duty to control towards the implementation of village order and its finance record (APBDes).

One of concept of good governance is participation. It is an activity that include civil society in some important decision. That is why, before the apparatus conduct the finance need for development of village, they must held conference with civil society to gather the aspiration directly from society. The conference must be done in order, the smallest civil society (known in Indonesia as RT/RW or neighbourhood) must held little conference and report the result to the head of the village. The order of ministry of home affairs number 113 of 2014 stated that finance planning program is started from APB according to the recent RKP village. The person who in charge to conduct its finance planning report is the village secretary. By the time it has written, the secretary will report the result to head of village. Then, the head of village will bring the report to the conference with BPD and decide whether the plan already meet the requirement or not. As approved by BPD, the finance planning will be sent to Regent, the process will take three to five days and it takes 20 days for Regent to evaluate the proposal. After that, the confirmation from Regent will decide whether the proposal is accepted or rejected.

Village Finance Implementation. According to APB result on previous step, it will be proceeded into implementation phase which cover Finance Consideration Arrangement, Letter of Payment Demand, Commodity/Service Arrangement and Field Implementation.

Finance Consideration Arrangement consists of the details of fundamental needs, component details, and the expenditure for each event. All of them will be conducted in the report $(R A B)$ and delivered to village secretary for verification. After verification phase, the secretary will transfer the documents into head of village for final approve and legalised. According to an interview with informant, all villages in Porong sub-district already submit their RAB documents and already followed the procedure within its line.

According to the order of ministry of home affairs number 113 of 2014, there are some general regulations must be obeyed by everyone which is stated on the implementation of village finance part as follows:

- Every expenditure and income traffic must use only one village treasury bank account in the name of right of village finance implementation (article 24 act 1 Permendagri (Ministry of home Affairs regulation) 113 of 2014)

- Every traffic of expenditure and income must be attached with legal bill of transaction proof (article 24 act 1 Permendagri (Ministry of home Affairs regulation) 113 of 2014)

- Any expenditure which become a burden for APB before the implementation of its arrangement will be considered as rule of village (article 26 act 1 Permendagri (Ministry of home Affairs regulation) 113 of 2014). An exception will be applied for certain need of Apparatus which is mandatory and office operational need which is already approved by head of village before.

According to points above, one village must possess one bank account on behalf of village governance. Any transaction and cash withdraw must be signed by head of village and its treasurer. Fortunately, for village in remote which does not posses banking service yet, the transaction will be handled by Regent or major of its area. It will help any third parties, normatively, to complete any transactions with the village.

The implementation of village finance expense consists of two major phases which are income expense and expenditure expense.

Income expense covers the previous SiLPA, secondary finance withdrawal and the result of village resource exploitation which is split. The residue of all consideration is known as Income Expense which later will be used to expense any on going event, it would help the village to save some deficit. The implementation of using SiLPA method must be included in APB documents. The secondary fund will be transferred into central village bank account which must be done within legal procedure

The examples of expenditure expense are the arrangement of secondary fund and the attachment of village capital. The arrangement of secondary fund is legalised after the verification within village order has been signed. The bank account of secondary fund is 
exclusive, the consideration of its time limit must not exceed last of current head village period. This system also applied on village capital arrangement, it must possess verification pass from BPD.

From thirteen villages, none of them use letter of payment demand when withdrawing the money. There is no verification from the secretary nor any signed confirmation from the head. Instead, all villages in Porong sub-district only use check signed by secretary and the head. In some cases, the amount of money does not match with the actual need.

This phenomenon does not in line with regulation from the government, Regent of Sidoarjo number 27 of 2015 about the instruction of finance management system article 34 act 1 and 2, article 35 and 36 which, in general, states that any proposal to conduct an event must be fully attached with RAB documents which is verified by secretary and approved by the head of village. As stated in RAB, the organizer of the event must sent the letter of payment demand to head of village which consist of (1) letter of payment demand, (2) declaration of expense responsibility, (3) attachment of transaction bill.

Finance Administration. Administration village finance is the act of note taking which is exclusively done by the village treasurer. To take a ote on every transaction of the village is mandatory duty of treasurer. Moreover, the treasurer must considerate systematically towards the chronology of every transaction traffic in the bank account.

In the observation field, there is no some serious problem in this system. Unfortunately, in some villages, village treasurer violates the code of finance system by faking the note that should be clearly stated in their village foundation book note (BKU). One of the village that violates the report is Lajuk. The village violates in a road barrier build project, paved road project, and water plumbing. There is a burden to RAB in the amount of Rp. 113.638.800,with the details as follow:

a. Road Barrier Construction in Pandokan area, according to the analysis of public service of 2016, the cost to install the river rocks is Rp.800.000,-/m3, the actual need of the project must be 132,72 m3xRp.800.000,- = Rp.189.148.900,- - Rp.106.176.000,- = Rp.82.972.900,-

b. Road barrier at 04-05 neighbourhood/02 hamlet carry the burden for the estimation for about Rp.86.339.000,- -Rp,61.760.000,- = Rp,24.579.000,--

c. Road Paving at 03 neighbourhood/03 hamlet is $15 \mathrm{~m} \times 3 \mathrm{~m}=45 \mathrm{~m} 2$. The transaction bill was .9.461.900,- $(45 \mathrm{~m} \times \mathrm{Rp} .210 .264,44)$ while the actual cost should be Rp.3.375.000.(45 m2 x Rp,75.000,-). Thus, the burden is Rp.6.086.900,-.

The conditions above do not in line with the regulation of Sidoarjo Regent number 54 of 2014 about the instruction of commodity/service implementation article 3 act (a) which states "the implementation of commodity and service at village must use minimum expenditure for any transaction towards the quality and the deadline of the project or it must uses approved fund to achieve the project goal within maximum quality"

Another finding from police inspection, according to ofly inspection of RAB of Lajuk village of 2016, there is SILPA of the previous of (2015), the amount reaches Rp.15.358.540,-. The head of village and the secretary confirmed that the money was used to build security outpost. Head of village and its treasurer confessed that they do not report the project into APB documents, the expenditure also could not be found on BKU.

The condition above violates the rule of Sidoarjo Regent Number 27 of 2015 about village finance management system chapter II:

- Article 2 act 1 states "finance management is conducted within transparency, accountable, participative, and concluded in order of consideraton"

- Article 37 act 3 which states that treasurer is the one who in charge to take a note of the expenditure and income of the village

There are some other findings that shows some unclear expenditure without letter of received payment and invoice attachment.

- BKU number 3, $9^{\text {th }}$ May 2016, electricity of the village is being upgraded which cost it about Rp.1.800.000,- achieved from CV. MAN 3 JAYA company without clear sign of the third party. 
- BKU number 6, $28^{\text {th }}$ June of 2016, there is an event called PIN that has been done on March 201, it costs the village Rp.1.400.000,-, there is no attendance list of the audience who may ormay not come to the event. The condition against Regent Rules number 27 of 2015 which states "every expenditure which becomes burden of village APB must be attached with legal documents".

Report. Article 35 Permendagri 113 of 2014 shows that the village treasurer is obliged to account for money through an accountability report. The accountability report is periodic semi-annual and annually and submitted to the Regent or Mayor and some are submitted to the Village Deliberation Agency. The first semester report is a report on the realization of APB submitted no later than the end of July of the current of. The final semester report is submitted no later than the end of January of the following of. From the research, it is known that the thirteen villages studied have reported the management of village finance either to BPD or to the Regent through the head of sub-district.

Responsibility. The responsibility to report the APB documents is on the charge of head of village. The document must be reported to Regent or mayor every end of the consideration semester. The documents consists of income, expenditure and expense report. The report of responsibility implementation of finance expenditure village is the report which is stated periodically sent to Village Deliberation Council towards the report of APB which is already approved in the beginning of first semester. The report must be conducted within principle of transparency and based on the order of society. Head of the village must inform its people the result of the report in written form and placed it in some media which is easily accessed by the public. Some helpful media to share the information in village area could be an announcement board, radio community, or another media. The information must not exceed later than a month since the information was received by apparatus. From the field observation, it can be concluded that all of villages has informed their people about the expenditure report of their village. Unfortunately, not all villages report their event details after a month as the event ended.

About the responsibility to manage the finance system, the responsibility is the product of authority, duty, and right of the apparatus. These three points are the major point that need a full responsibility for every reports that they have made. The word 'responsibility', literary, means mandatory condition for being responsible of anything happened during their authority (people could sue, blame, and demand). According to Istanto, responsibility means that we need to be able to serve an answer which is the result for everything happened and it is a mandatory to regain for every mistakes occurred during the event (Istanto,1994:77). Every phase of finance expenditure, planning, implementation, responsibility, and the evaluation must be followed with responsibility of every actors included in the event, thus it will create good governance among villagers. Responsibility comes because of authority. The definition of authority based on general meaning and language is (a) the right and power to act or to do something, (b) authority makes decision to rule and accept to be responsible to other people (Anton M.Moeliono, 1995:533).

According to Soekanto, he stated that authority is a power possessed by individual or community which have support from other community or it has people trust. Meanwhile, according to H. D. Stout, he states :"Bevoegheid ... wat kan worden omscreven als het geheel van regels dat betrekking heft op de verkrijging en ultoevening van bestuursrechtelljke bevoehgdheden door publiekrechtelijke rechtssubjekten in het bestuursrechtelijke rechtsverkeer (The authority ... can be explained as a whole the rules relating to the acquisition and use of governmental authority by the subject of public law in public legal relations) (Fachruddin Irfan, 2004:39).

According to Philipus M.Hadjon, as civil concept of law, authority must possesses at least three components, they are influence, fundamental law, and law conformity. Influence component is an understanding that authority is used to control subject of law behavior. This component is meant for apparatus, they must not use their authority out of public interest which is clearly stated in the constitution (Abdul Latif, $2014: 7$ )

In reality, the authority given to state administration apparatus is violated. It does not in line with the vision of country, it is known as "Discretion" 
The concept of bestuur (besturen) the authority of government is not merely a power to control but it is also as discretionary power or feis ermessen. There is another type of authority proposed by Indroharto, it is facultative authority, this authority possessed by apparatus which is not mandatory to use it or the apparatus could choose many other options instead of executing their facultative authority, but there is condition that the faculatative authority is the only option .( Indroharto, 2000:99-101).

Parameters of authority violation on the type of authority are bound by the draft rules, or use the parameters of the legality principle, whereas in the discretionary authority the parameters of abuse of authority use the general principles of good governance, since the principle of "wetmatigheid" is inadequate.

Authority Misuse And Procedure Faulty based on the experiments through 13 villages in Porong sub-district, there are some violation found on finance management system, as follow:

Planning Phase. The result of experiments show that from 13 villages, there are 7 villages that had conduct their RPJM report while the other 6 could not afford to show the documents. In the other hand, for RKP documents, all villages could not present the report. Based on specialization principle adopted by positive law, it is Law number 7 of 2003 about state financial, the phenomenon could be identified as violation of law and authority misuse as it already fullfil the minimum requirement to be identified as authority misuse. Based on specialty principle, it is stated that the authority of government to act for a goal, every authority of government is controlled by law within a clear vision. The vision can be reached if a good planning is well prepared. In the other hand, 6 villages from 13 villages does not prepare their planning system, this is a simple example of procedure faulty done by administration staff. In connection with legality principle, the phenomenon is also considered as procedure faulty and authority misuse, RPJM documents is the document of vision and mission of the village conducted by the head of village, meanwhile, RKP is the details of the visions and mission which could last for a year. If the village does not reproduce and evaluate the RKP and RPJM documents, it means a violation to Law of ministry of home affairs number 114 article 5 act 1-3 about the instruction of village development, it states:

1) In order to create village development planning, which is already stated in article 4 , the village governance must do as follows:

a) Arrange RPJM documents

b) Arrange RKP documents

2) RPJM document, whereas stated in act 1 alphabet a, it is agreed that the document must be completed no later than 3 months since the first day of head of village coronation.

3) RKP documents must start its arrangement on July in the following year.

Implementation Phase. The results found in observation field shows that there are some villages which is unable to show their RAB report, there are no valid evidence, and the cost of building project which exceed the actual need, the construction which is not stated in the village consideration, BPD support, finance administration fee, and woman modin, the trip of village secretary did not sent to the one who must receive it, there is no bill legal bill in some transactions, the notes which is invalid. Illegal taxes which is not yet transferred to state finance and money withdrawal which is not valid on its procedure, the valid procedure must follow and offer RAB and SPP proposals. Instead, they are able to cashing the check which is only signed by he village treasurer and the head of village, even the amount of money exceed the need.

From the benchmarks presented by Mariette Kobussen that is from the principle of specialty. It shows that in the implementation of village finances there has been irregularities of authority because it is not in accordance with the objectives of village financial management, and on the principle of specialization of the relationship of legality principles of financial management officials do not implement the law related to village financial management as follow:

a) the rule of Regent number 4 of 204 about the instruction of commodity and service arrangement in village article 3 alphabet (a) which stated that: the commodity and service supplying must apply the principle of Efficient which means that it must use the minimum 
cost and effort, or it could use the agreed fund to achieve the maximum quality of the commodity or the service.

b) the rule of Regent number 27 of 207 about the instruction of village finance management system chapter II, it is on article 2 act 1 which stated: the finance management sytem of village must be proceeded based on the principle of transparency, accountable, participative, orderly and discipline. Meanwhile, the article 32 act states: "every expenditure of the state expense which become burden of village APB must be attached with valid and legal evidence", article 37 act 3 which stated that the treasurer of village must take a note on every traffic of transaction of the village. Moreover, the article 38 states: "Treasurer as a mandatory to collect the taxes of Pph and other taxes must deliver all of the taxes to the state bank account within a recent regulation"

from the principle of misuse authority and procedure violation, money withdrawal without full report of RAB and SPP is clearly considered as procedure violation as the condition is not in line with regulation of Regent number 27 of 2015 article 1 and 2, article 35, and article 36 which conclude :" Implementation of activities in proposing funding for carrying out activities shall be accompanied by a document of the Budget Plan verified by the Village Secretary and authorized by the Village Head, based on the Letter of Payment Request (SPP) to the Village Head. Submission of SPP consists of (1) Payment Request Letter (SPP), (2) Statement of expenditure responsibilities and (3) Attachment of transaction evidence"

Administration Phase. The result of experiment found that the secretary as the apparatus of administration office has well done the job description maximally, there are some events did not recorded on BKU documents, there are some taxes which is not transferred to the office of ministry of finance, and invalid evidence of expenditure. This shows that in administration phase, there are still authority misuses, the secretary confessed that there are some events which is not recorded to BKU documents. Thus, the actors are realized that they have misuse their authority.

Reporting Phase. The study reveals that there is no any violation found during the reporting progress. Because, the reporting phase becomes major requirement for a village to propose budget for an event, they conduct the documents in time.

According to rule of ministry of home affairs number 113 of 2014 about finance management article 37 stated that the head of village must report the realization of village APB to Regent or Mayor in the form of first semester and the end of the year. The report must be conducted periodically every semester, the first semester should finish on late July and the end-year report should take on January of the next year.

Responsibility Phase. The responsible report of APB implementation will be delivered by head of village, Regent, or the Mayor every end of consideration year. The report consists of several documents. They are income report, expense, and expenditure report. The study shows that there is no violation or misuse authority in this phase. From thirteen villages as the subject of study, there are some violations in finance managing phase which make states lost some amount of money and somebody rights are not delivered caused by this violation. The next question is who should be responsible for this case.

The study reveals that the thirteen villages violate and misuse the budget of the state, this against the actual goal of finance management system of state, the actors will be punished based on the recent constitution as finance violation is one of corruption act in this country. The budget of village which come from APBN and APBD is the budget of state, the violation of them will be considered as corruption and criminal act. In the rule of criminal law, we follow the principle of "personal responsibility" which means criminal act is individual responsibility.

The government published law number 30 of 2014 about the state administration, this law guarantee the fundamental rights and protect the society and also guarantee the implementation of state event.

According to the theory of rule of law proposed by Immanuel Kant and Hans Kelsen, they mentioned State in principle is not based on mere power (machtsstaat) but must be based on law (rechtsstaat) (Marbun, 1997: 8.). Thus, Law number 30 of 2014 is expected not 
only as a legal protection for governance. But also as an instrument to improve the quality of government services to the community so that the realization of good governance for all agencies or Government Officials in the Central and Regional.

Law number 30 of 2014 about state administration article 20 states:

1) Supervising towards the authority misuse by intern governance supervisor which is stated already in article 17 and 18.

2) Result of the supervising by intern governance supervisor which is stated in act as follows: there is no violation; administration invalid or administration invalis which result in state financial lost.

3) If the supervisor find invalid administration report as stated in act 2 alphabet a, there must be revising on the invalid administration based on the recent constitution

4 ) If the supervisor find invalid administration report which result in state financial lost as stated in act 2 alphabet $b$, the refunding of the amount of financial lost is mandatory no later than 10 days of normal working day as the announcement from supervisor is published.

5) The refunding process as stated in article 4 is the responsibility of government council, if the violation in article 2 alphabet $c$ is not the result of authority misuse.

6 ) the refunding responsibility as stated in article 4 become responsibility of state apparatus if the invalid administration as stated in article act 2 alphabet $c$ is the result of authority misuse.

The articles above explained that the implementation of state finance recognized by the state apparatus gain law protection from the constitution as society by the time law number 30 of 2014 is published about state administration, supervising act is the duty of intern governance apparatus as initiation to prevent authority misuse by the apparatus. The result of the supervising act will be evaluated if there is any invalid report of administration documents which result in financial lost to the state. Thus, the revising and fixing the error is mandatory for government council or it is the responsibility of the corruptors to return the amount of money they had violated in this case is the head of village. This is the preventive law protection to prevent lawsuit. But, if there is no any responds from the head of village, the repressive law will be applied on him/her, it is a protection for the actors to finish the lawsuit, it is one of criminal law. The authority misuse done by the state apparatus must face the judgment and finish the lawsuit.

\section{CONCLUSION AND SUGGESTIONS}

From several experiments based on literature or observation field above, there are some conclusions as follow:

The finance management system in Porong Sub-district Sidoarjo regency, based on good governance principle, generally, is already followed the procedure in planning, implementation, administration, reporting, and responsibility of the finance. Unfortunately, the act is not completely follow the instruction of the constitution, the lack of transparency and accountability are no more than just a procedure to cashing their budget. Thus, good governance is not yet maximum on this area. In managing the finance, the apparatus is guaranteed by law protection by law number 30 of 2014 about state administration. The supervising is the duty of intern governance supervisor as the prevention for other apparatus to use their authority based on law If the supervisor find invalid administration report which result in state financial lost, the refunding of the amount of financial lost is mandatory no later than 10 days of normal working day as the announcement from supervisor is published. the revising and fixing the error is mandatory for government council or it is the responsibility of the corruptors to return the amount of money they had violated in this case is the head of village as the one who responsible finance management.

According to the conclusion above, there are some recommendations as follow: there must be workshop or training about good finance management system in village level for the apparatus of the villages. There must be a socialization on the responsibility of managing valid report by doing direct practical work. The idea will be much better with the support of 
LSM and local governance. The last, evaluation by the society is very important to improve the transparency of the village finance management status.

\section{REFERENCES}

1. Irfan, Fachruddin. (2004), Pengawasan Peradilan Administrasi Terhadap Tindakan Pemerintah, Alumni Bandung, 2004.

2. Indroharto. Usaha Memahami Undang-Undang Tentang Peradilan Tata Usaha Negara: Buku I Beberapa Pengertian Dasar Hukum Tata Usaha Negaral. Jakarta: Pustaka Sinar Harapan. 2000.

3. Istanto, F.Soegeng, (1994), Hukum Internasional, UAJ ,Yogyakarta

4. Moeliono, Anton dkk. (1995) Kamus Umum Bahasa Indonesia, Balai Pustaka, Jakarta.

5. Nasution. (2008). Metode Penelitian IImu Hukum. Bandung: Mandar Maju.

6. Latif, Abdul, Hukum Administrasi, Perdana Media Group, Jakarta, 2014.

7. Marbun, Pengadilan Administrasi Negara dan upaya administratif di Indonesia, Liberty Yogyakarta, 1997. 